\title{
Innovation decision of Tunisian service firms: an empirical analysis
}

\author{
Hanen Sdiri and Mohamed Ayadi
}

\author{
* Correspondence: \\ sdirihanen@gmail.com \\ UAQUAP-Tunis Higher Institute of \\ Management, 41 Rue de la liberté, \\ 2000 le Bardo, Tunisia
}

\begin{abstract}
The purpose of this paper is twofold. First, it investigates the way by which Tunisian service firms make their decision to innovate: simultaneously (one-stage model) or sequentially (two-stage model). Afterwards, once the innovation-making-decision way is selected, the paper analyzes its main determinants. Using a sample of 108 Tunisian service firms, the paper reveals that the two-stage model has a statistically significant advantage in predicting innovation. Indeed, it is shown that the sequential model illustrates well the innovation making-decision procedures. In fact, the main determinant behind the dominance of the sequential model is the importance that service firms give to the innovation objectives.
\end{abstract}

Keywords: Innovation, Decision making, Service sector

JEL classification: L80, O31, O32

\section{Introduction}

Innovation activities have always been considered as the major driver of economic growth and competitiveness (Schumpeter, 1934). The literature on innovation shows that innovators are more efficient and more productive in comparison with noninnovators (Mansury and Love, 2008). Thus, increasing the innovation capacity is an aim that any firm targets. Innovation surveys demonstrate that, in developed countries, the product or service innovations are abundant activities. For example, about $80 \%$ of the U.S companies introduce at least one new service (Mansury and Love, 2008) and almost half of the Irish firms undertake an innovation measure in their production chain (Roper and Dundas, 1998). Due to their increasing needs to innovation in order to confront not only the fierce competition but also the unsteady way through which the consumers perceive the quality of their products, manufacturing firms have also a tendency to resort to open innovation. This is defined in Chesbrough (2003) as: "the usage of knowledge inflow and outflow from the corporation to accelerate internal innovations and maximize their value by enlarging the market for external utilization". 1

Moreover, service companies introduce new services in order to increase their market share and therefore to maintain their position in a highly competitive environment. In some Information and Communications Technologies (ICT) sectors, innovation is vital for the survival of ICT business firms. In others, such as low-tech sectors, the introduction of new services is also required so as to capture additional market shares. In developing and emerging countries, service innovation is going to play an important

(C) 2016 The Author(s). Open Access This article is distributed under the terms of the Creative Commons Attribution 4.0 International License (http://creativecommons.org/licenses/by/4.0/), which permits unrestricted use, distribution, and reproduction in any medium, provided you give appropriate credit to the original author(s) and the source, provide a link to the Creative Commons license, and indicate if changes were made. 
role in promoting these countries' economies. However, the magnitude of such an innovation remains insufficient to meet the drastic increase in the service demand. The quickly growing interest of service firms to open innovation is also remarkable. These firms are strongly interactive. In some cases, the supply of one service by one firm requires the supply of another one by other firms. Indeed, they are urged to collaborate and exchange innovation-related ideas. This open-innovation-related behavior of service firms becomes fundamental but it is rarely studied in the empirical service innovation literature. ${ }^{2}$

Tunisia, considered as an emerging country, has devoted a remarkable endeavor to service innovation. The program called "Pour la Tunisie de demain"3 has been adopted in order to support Tunisian service firms to avoid foreign competition. The program has called for the encouragement of innovative companies, the intensification of the cooperation projects, the implementation of several techno-parks and the establishment of the information society bases.

Innovation has been widely studied in the economic literature. Some empirical studies focus only on explaining the impact of innovation on the performance of manufacturing firms (Crépon et al., 1998; Mairesse and Mohnen, 2003; Roper and Dundas, 1998 and Cainelli et al., 2006). Other ones analyze the determinants of innovation and the role of external linkages while introducing external control factors such as the firm's size and age (Duguet, 2006; Raymond and St-Pierre, 2010). The study of the determinants and effects of innovation distinguishes merely between two types of innovation: product innovation and process innovation. Other studies distinguish between new-to-market and new-to-firm service innovation, which makes up the object of our paper. New-to-firm means that innovation is going to be new to the firm but it has been already launched by the competitors. New-to- market assumes that the firm is the first and the sole to have launched a new service on the market.

The recent works are not delimited to the analysis of the pre-cited determinants of innovation, but they are interested in analyzing the innovation decision-making procedure. $\mathrm{Du}$ et al. (2007) are the first to examine this procedure but for the case of Irish manufacturing firms. However, to our best knowledge, no one has yet explored service innovation decision-making for emerging countries and more precisely for Tunisia.

In this paper, we address the following two questions: how do Tunisian service firms make their decision to innovate? Are these decisions simultaneous or sequential? Broadly speaking, we consider two alternative models of the innovation decision: the one-stage model (where the innovation choice is simultaneous) and the two-stage model (where the innovation choice is sequential).

The paper is organized as follows. Service innovation analysis presents a brief literature review on innovation decision. Models and estimations sets out the econometric models. Data and variables contains a description of the data set and the variables used in the empirical analysis. The results of the empirical analysis are in Empirical results. Conclusions synthesizes the main empirical findings.

\section{Service innovation analysis}

We distinguish between the literature that deals with the types of service innovation and the one that investigates the innovation decision. 
Types of service innovation

Numerous are the studies that have identified the main patterns that innovation holds. According to the OCDE (2005) innovation report, innovations are classified into four categories: product innovation, process innovation, organizational innovation, and marketing innovation. A product innovation is the introduction of some significant changes in the product characteristics. Process innovation represents significant changes in both production and distribution methods. The organizational innovation is defined as the new management forms that firms adopt. The marketing innovation takes the form of carrying on new commercialization method (for instance, change in the product design, product pricing method, etc.).

Gallouj and Weinstein (1997) consider products as a result of characteristics and skills series. In the same line with Gallouj and Weinstein (1997), Mansury and Love (2008) show that product innovation patterns, mainly developed for the manufacturing industry, may not apply easily to services. They insist on the fact that the traditional distinction between product and process innovation is less useful in the service context. The reasons behind this fact are related to the ambiguous nature of service outputs and the simultaneous production and consumption of services. Other frameworks distinguish between radical innovation and incremental innovation (Sundbo and Gallouj, 1998). This distinction has been the object of some empirical studies. For instance, Brouwer and Kleinknecht (1996) have studied it for Netherlands, Duguet (2006) for France, Baldwin and Hanel (2003) for Canada, Mansury and Love (2008) for USA and finally Lööf and Heshmati (2006) for Finland, Norway and Sweden.

\section{The innovation decision}

Cabagnols and Le Bas (2002) explain the determinant of the choice between three types of innovation decisions: to innovate only on product, to innovate only on process and to innovate on both product and process. Specifically, these authors clarify the way by which French firms orient their decisions to innovate. But, one of the issues addressed by this recent literature is whether it is a one-stage or a two-stage process. Du et al. (2007) test the performance of two models of decision making: the simultaneous and the sequential model. They show that the sequential model (two-stage innovation decision) is more efficient than the simultaneous model (one-stage innovation decisions). More recently, Bourke and Jordan (2015) examine how the Irish high-technology companies make their decisions to innovate. These authors suggest that the adoption of the two-stage innovation decision-making model explains better the influence of the available sources on different types of innovation. In fact, the works that have investigated service firms' innovation decision-making procedures remain relatively rare. Our paper contributes to this literature by focusing on the service companies in Tunisia, regarded as an emerging country.

To model the innovation decision-making, we apply the two models proposed by Du et al. (2007) based on two forms of decision making: The one-stage model and the two-stage model. In this paper, we are interested in studying the innovation in the service sector and in determining the decision to choose between new-to-firm innovation and new-to-market innovation. Our one-stage model (simultaneous decision) supposes that a service firm confronts four alternatives for innovation choices: 
no-innovation, new-to-market only, new-to-firm only and both new-to-market and new-to-firm. However, the two-stage model (sequential decision) assumes that the firm decides first whether or not to undertake innovation activity and then considers which category of innovation it would engage in. The following Figure depicts the firms' innovation activity decision tree (Fig. 1).

The econometric estimation we adopt is based on certain estimation tools of the discrete choice models. Indeed, the econometric estimation procedure depends on whether the choice of an innovation is sequential or simultaneous.

\section{Models and estimations}

\section{One-stage model}

Regarding the one-stage model, the innovation decision is considered to be a four outcome discrete variable. For this reason, we use a Multinomial Probit model (MNP).

This model allows relaxation of the Independence for Irrelevant Alternatives (IIA) propriety. It has the advantage of permitting a much more flexible pattern of error correlation. ${ }^{4}$

We assume that firm $i$ faces $J$ choices, the utility $U_{i j}$ of choice $j$ is the sum of a deterministic component $X_{i j}^{\prime}$ and an unobserved random component $\varepsilon_{i j}$. The utility function is then expressed as follows:

$$
U_{i j}=X_{i j}^{\prime} \beta_{i j}+\varepsilon_{i j}\left[\varepsilon_{i 0}, \varepsilon_{i 1}, \varepsilon_{i 2}, \varepsilon_{i 3}\right] \sim N\left[0, \sum\right]
$$

Where $j=0$ represents the firm's decision to choose not to innovate at all, $j=1$ if the firm introduces a new-to-market only, $j=2$ if it introduces a new-to-firm only and finally $j=3$ if it introduces both innovation.

If the firm makes choice $j$, then its utility $U_{i j}$ is the maximum among the 4 utilities. Therefore, the statistical model is driven by the probability that choice $j$ is made. It is expressed as follows:

$$
\begin{aligned}
P_{i j} & =\operatorname{Pr}\left(Y_{i}=j\right), \forall k \neq j \\
& =\operatorname{Pr}\left(U_{i j}>U_{i k}\right) \\
& =\operatorname{Pr}\left(\varepsilon_{i k}-\varepsilon_{i j} \leq\left(X_{i j}-X_{i k}\right)^{\prime} \beta\right)
\end{aligned}
$$

The vector of $\beta$ coefficients is estimated using the maximum likelihood method. The log-likelihood can be derived by attributing, for each firm, $y_{i j}=1$ if alternative $j$ is chosen by the firm $i$ and 0 if not, for the 4 possible outcomes. The log-likelihood is:

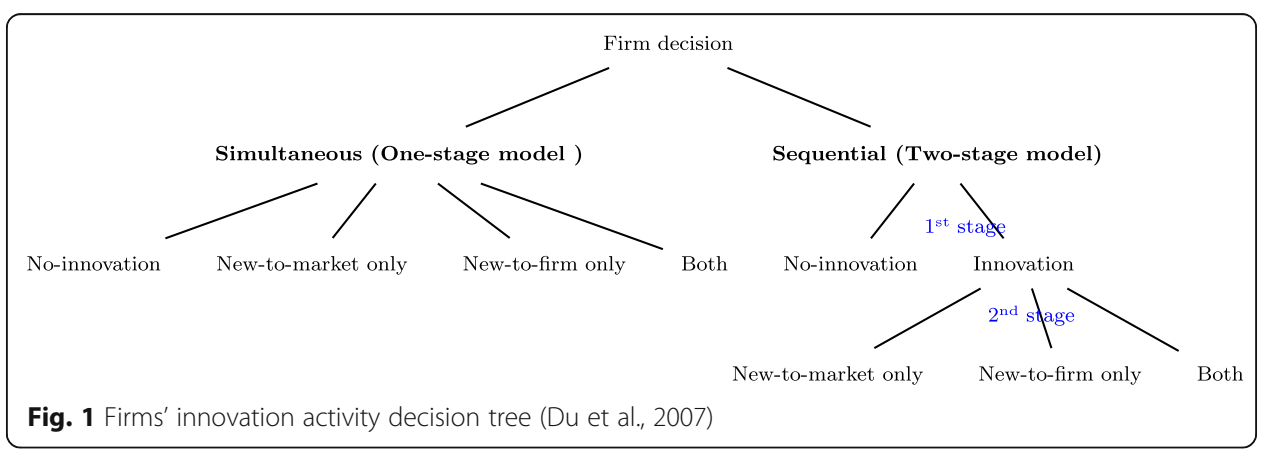




$$
\begin{aligned}
\log L & =\log \left\{\prod_{i=1}^{n} \prod_{j=0}^{3} \operatorname{Pr}\left(Y_{i}=j\right)^{y_{i j}}\right\} \\
& =\sum_{i=1}^{n} \sum_{j=0}^{3} y_{i j} \log \operatorname{Pr}\left(Y_{i}=j\right)
\end{aligned}
$$

\section{Two-stage model}

The two-stage model is the sequential decision of innovation. It assumes that the firm first decides whether or not to engage in any innovation activity and then it considers what category of innovation it would participate in. In the first stage, we consider a binary choice model in order to model the probability of whether or not the firm makes the decision to innovate. We use a Probit model because the dependant variable is binary.

$$
\operatorname{Pr}\left(Y_{i}=1 \mid X_{i}\right)=\int_{-\infty}^{X^{\prime} \beta} \phi(t) d t=\Phi\left(X_{i}^{\prime} \beta\right)
$$

Where, $\Phi($.$) is a commonly used notation for the standard normal distribution which$ is given by $F\left(X_{i}^{\prime} \beta\right)=\Phi\left(X_{i}^{\prime} \beta\right)=\int_{-\infty}^{X_{i}^{\prime} \beta} \frac{1}{\sqrt{2 \pi}} \exp \left\{\frac{-t^{2}}{2}\right\} d t$. Then, the coefficients are estimated using the maximum likelihood method such that:

$$
\log L=\sum_{y_{i}=1}^{n} y_{i} \log \Phi\left(X_{i}^{\prime} \beta\right)+\sum_{y_{i}=0}^{n}\left(1-y_{i}\right) \log \left[1-\Phi\left(X_{i}^{\prime} \beta\right)\right]
$$

If the decision to innovate is made (the first stage) then the firm (at the second stage) will choose which type of innovation to engage in. As in the first model, we consider again an MNP with three choices: (1) new-to-market only, (2) new-to-firm only and (3) both. The log-likelihood is thus:

$$
\log L=\sum_{i=1}^{n} \sum_{j=1}^{3} y_{i j} \log \operatorname{Pr}\left(Y_{i}=j\right)
$$

\section{Data and variables}

In this section, we examine the main characteristics of the data and the indicators used in our empirical analysis.

Data

In this paper, we use data from a survey of 108 Tunisian service firms. Data were collected through a questionnaire which was distributed to some Tunisian service firms. ${ }^{5}$ Although our analysis is about the issue of innovation in the service sector, our sample consists of firms that mainly provide value-added services:

- The ICT-based services according to the nomenclature published in "The directory of ICT in Tunisia"

- The Banks listed in the "Tunisia's Professional Association of Banks and Financial Institutions (APTBEF)" 
- Insurance Companies that are listed in the "Tunisian Federation of Insurance Companies (FTUSA)".

Out of 200 questionnaires distributed, only 108 usable responses were obtained, representing a response rate of $54 \%$. The questionnaire is a modified version of the third community survey on innovation CIS III and the second European survey on innovation 1997. The survey collects information that concerns the firms' innovation activities over the period 2005-2007 and some information on the innovation patterns (Sdiri et al., 2010). It involves also information about the service firms' features (their size, their vintage, the skills they employ, the group they are belonging to, etc.), their expenditure devoted to $R \& D$ and innovation activities and innovation objectives.

Our sample has been stratified by NAT ${ }^{6}$ size (7 classes by number of employees: $1-6$, $7-9,10-19,20-49,50-90,100-199,200$ and over). For each class, we associate a weight representing the weight of this bracket at the national level in order to obtain a more representative sample of the global population.

Table 1 below summarizes the determinants of the weighting operation. It shows that $21.30 \%$ of respondents come from small firms (number of employees is lower than 6). Furthermore, this table reveals that $9.26 \%$ of the interviewed firms claim that they introduce a new-to-market innovation, $16.66 \%$ introduce a new-to-firm innovation and $52.77 \%$ introduce both kinds of innovation.

\section{The variables}

\section{Service innovation}

To analyze the determinant and the patterns of innovation, the majority of the previous studies have measured the innovation output by the number of patents or the percentage of new product sales (Mairesse and Mohnen, 2003). Yet, these indicators cannot be used in our case. Indeed, the number of patents is not a good indicator for the emerging countries where the number of patents is extremely limited especially for service innovation. So, we use three other innovation measures.

- First, we measure the innovation output (INSERV) by a binary variable taking the value 1 if the firm has innovated over the previous three years and 0 otherwise.

Table 1 Distribution of the firms according to the size

\begin{tabular}{lllllllll}
\hline Size & Total & & & & $\begin{array}{l}\text { New-to-market } \\
(\%)\end{array}$ & $\begin{array}{l}\text { New-to-firm } \\
(\%)\end{array}$ & $\begin{array}{l}\text { Both } \\
(\%)\end{array}$ \\
\cline { 2 - 5 } & $\begin{array}{l}\text { Number of } \\
\text { respondents }\end{array}$ & INS' firms & Corrected weight & $\%$ & & & & \\
\hline $1-6$ & 23 & 12649 & 903.5 & 21.30 & 20 & 5.55 & 24.56 \\
$7-9$ & 17 & 785 & 78.5 & 15.74 & 0 & 16.66 & 15.78 \\
$10-19$ & 18 & 713 & 89.125 & 16.67 & 10 & 27.77 & 15.54 \\
$20-49$ & 13 & 509 & 63.625 & 12.04 & 30 & 5.55 & 12.28 \\
$50-90$ & 10 & 230 & 38.33 & 9.26 & 0 & 11.11 & 7.01 \\
$100-199$ & 10 & 167 & 18.55 & 9.26 & 10 & 11.11 & 7.01 \\
$\geq 200$ & 17 & 215 & 13.43 & 15.74 & 30 & 22.22 & 15.78 \\
Total & 108 & 15268 & 215.04 & 100 & 9.26 & 16.66 & 52.77 \\
\hline
\end{tabular}


This measure is obtained by asking informants to indicate if the firm has introduced or not a new or a significant improved product and/or process;

- Second and for the one-stage model, the innovation decision is measured by a discrete variable with four outcomes $(\mathrm{InDec})$. In this case, the firm faces four choices: (0) no-innovation, (1) new-to-market innovation, (2) new-to-firm innovation or (3) both;

- Third and in the two-stage model, the innovation decision is measured by a discrete variable with only three outcomes (InDecII).

\section{Size and vintage of the firm}

The relationship between innovation and firm size has been thoroughly examined in several works. In this paper, we measure the firm size (SIZE) by the total number of employees in 2007. The firm's vintage $(A G E)$ is determined by the date of its creation. More precisely, this measure indicates the number of years during which the service firm has acted in the market until 2007.

\section{Education level}

The availability of human capital inside the plant with an appropriate level of skills and knowledge in R\&D activities is considered as the essential internal resources that enable the firm to innovate. In fact, the education level represents, on the one hand, an indicator of the know-how and skills level of an employee and, on the other hand, a major determinant for making innovation activities. In this paper, our education level measurement $(Q U A L)$ is the number of skilled workforce divided by the total number of employees in the firm.

\section{Group membership}

APP_GROUP is a dummy variable which takes 1 if the firm belongs to a group and 0 otherwise. When the firm is a member of a group, it has the advantage of learning from the competencies and the technological experience of other firms of the group and therefore has an important opportunity to innovate (Paul et al., 2000). So, the firm that belongs to one group learns from the other firms in terms of market-related opportunities.

\section{Cooperation and commitment in innovation activities}

Cooperation plays a prominent role in enhancing the ability of the firm to innovate. In this paper, we introduce the variable cooperation (COOPER) as a binary variable indicating whether or not the firm has signed any cooperation contracts, over the period 2005-2007, cooperation contracts with other external actors. This variable is introduced into the model to show that external relationships are indispensable to promote innovation. The previous empirical studies show that cooperation is positively related to innovation, implying that innovation activities require cooperation agreements with public or private agencies and with the other firms as well (Cohen and Levinthal, 1990).

According to the innovation economic literature, the R\&D investment is often regarded as a key determinant for innovation activities. In this paper, and because of the unavailability of such measure, we consider a qualitative variable (ENGAG), i.e. the 
variable takes the value 1 if the firm questioned has developed between 2005 and 2007 at least one of the innovation activities (including the intramural and extramural R\&D) and 0 otherwise. These activities are identified in Table 2 below.

\section{International orientation}

According to the empirical works on innovation and international trade, we notice that not all firms are able to benefit from innovation. Thus, it is essential to moderate the relationship between innovation and performance by the international orientation of the firm. This latter needs then a certain level of international orientation or internationalization ${ }^{7}$ so that it can be competitive not only in the domestic markets but also in the international ones. It benefits from their new products and/or processes. In this paper, we measure the international orientation (INTER) through a binary variable that takes 1 if the firm is engaged in internationalization strategies and 0 otherwise.

\section{The aims of innovation}

In order to achieve its objectives, a firm has to take into account a certain number of actions that can incorporate the R\&D and innovation activities. The introduction of the innovation objectives indicator in our regression is thus necessary. We consider a qualitative measure which is the importance that a firm gives to a set of factors influencing innovation activities (a five-point' scale of likert). In fact, firms were asked to answer five questions indicating the importance they attach to different objectives of innovation. The objectives we used in this study are: replace services that are removed (SERV_OBS), improve the service quality (QUAL_SERV), extend the line of the products (GAM_SERV), sustain the market share (PART_MAR) and decrease the production costs (RED_COUT).

\section{Empirical results}

Tables 4 and 5 report the results of the econometric estimation of the models discussed above: the sequential model and the simultaneous model. These models analyze the innovation decision-making process in the Tunisian services sector. Further, they enable us to explore the robustness of the two innovation decisions.

\section{Test of significance of the models}

The econometric specifications have a predictive power that exceeds $61.11 \%$ for the one-stage model and $68.23 \%$ for the two-stage model (Table 3). The whole significance of our models is confirmed by the McFadden R-squared, which is about $42.07 \%$ for the first model and about $44 \%$ for the second model. Thus, to select the appropriate

Table 2 Firm's innovation activities

\begin{tabular}{ll}
\hline Codes & Activities \\
\hline R\&Dint & Experimental R\&D (R\&D in house) \\
R\&Dext & Acquisition of services of R\&D (R\&D external) \\
MACH & Acquisition of equipment related to the technological innovations \\
LOGC & Acquisition of software and other external technologies related to the technological innovations \\
FORM & Training of personnel related to the innovation process \\
MARK & Internal/external marketing strategy for service innovation \\
\hline
\end{tabular}


Table 3 Prediction statistics

\begin{tabular}{|c|c|c|c|c|c|c|}
\hline & \multicolumn{2}{|c|}{ Actual probability } & \multicolumn{2}{|l|}{ One-stage model } & \multicolumn{2}{|l|}{ Two-stage model } \\
\hline & Number & $\%$ & Predicted probability & $\%$ & Predicted probability & $\%$ \\
\hline 0: No-innovation & 23 & 21.30 & 13 & 12.04 & - & - \\
\hline 1: New-to-market & 10 & 9.26 & 4 & 3.70 & 5 & 5.88 \\
\hline 2: New-to-firm & 18 & 16.67 & 3 & 2.78 & 3 & 3.53 \\
\hline 3: Both & 57 & 52.78 & 46 & 42.59 & 50 & 58.82 \\
\hline Number of observation 1-3 & 85 & & & & 58 & \\
\hline Number of observation 0-3 & 108 & & 66 & & & \\
\hline Correct prediction rate & & & 61.11 & & 68.23 & \\
\hline
\end{tabular}

model, we use the likelihood ratio $\operatorname{test}^{8} L R=-2\left[\log L\left(\widehat{\beta}_{M V}^{*}\right)-\log L\left(\widehat{\beta}_{M V}\right)\right]$, the Akaike information criterion (Akaike, 1974) $A I C=-2 L L+2 k$ and the Bayesian information criterion (Schwarz, 1978) $B I C=-2 L L+k \log (n)$, where $k$ is the parameter number, $L L$ is the $\log$ maximum likelihood and $n$ is the number of observations. These two criteria are given in Tables 4 and 5 . Based on the McFadden R-squared, the information criteria and the prediction percentage, we note that the two-stage model has a statistically more significant advantage than the one-stage model. Then, we show that the sequential model illustrates better the innovation making-decision procedures. This result has been also obtained by Du et al. (2007).

Table 3 shows that the proportions of the service firms that adopt new-to-market and new-to-firm innovations are higher under the sequential model in comparison with the simultaneous one. Indeed, a large part of the Tunisian service firms are highly incited to undertake radical innovation if their innovation decision-making is made through two stages. The possible intuition behind this interesting finding is that radical innovation may be so risky that firms need more time and resources before undertaking it.

\section{Determinants of the innovation choice}

After having shown that the sequential model is a better procedure of the innovation decision-making, we now analyze the main determinants affecting the choice between types of innovation.

As for the impact of the firm's size on the innovation decisions, the results already obtained in the empirical literature are very divergent. In our service innovation context, we show that $S I Z E$ has a negative and statistically significant effect on the choice a firm makes among the different types of service innovation. In addition, when the square of SIZE is also taken into account, the coefficient associated with it is positive and significant. This implies that the relationship between size and joint innovation is $U$-shaped. Actually, this outcome is considered to be the main result obtained in the empirical literature dealing with innovation. However, in the case of a manufacturing industry context, Du et al. (2007) find a positive effect of the firm's size on the ability to innovate but with decreasing rates. They also show that the distinction between the different types of innovation does not depend on the manufacturing company's size. An interesting result concerns the role of the cooperation variable (Cooper). We show that, when a firm cooperates with external partners (customers, competitors, universities, 
Table 4 Marginal effects of multinomial Probit model for innovation choice (first model)

\begin{tabular}{|c|c|c|c|c|c|c|c|c|}
\hline \multirow[t]{3}{*}{ Variables } & \multicolumn{8}{|c|}{ Multinomial Probit model } \\
\hline & \multicolumn{2}{|c|}{ No-innovation } & \multicolumn{2}{|c|}{$\begin{array}{l}\text { New-to-market } \\
\text { only }\end{array}$} & \multicolumn{2}{|c|}{$\begin{array}{l}\text { New-to-firm } \\
\text { only }\end{array}$} & \multicolumn{2}{|l|}{ Both } \\
\hline & $d y / d x$ & SE & $d y / d x$ & SE & $d y / d x$ & SE & $d y / d x$ & SE \\
\hline \multicolumn{9}{|l|}{ Internal knowledge sourcing } \\
\hline $\begin{array}{l}\text { Engaging in innovation activities } \\
\text { (ENGAG) }\end{array}$ & 0.104 & 0.110 & -0.058 & 0.041 & -0.026 & 0.023 & -0.019 & 0.123 \\
\hline \multicolumn{9}{|l|}{ External knowledge sourcing } \\
\hline Cooperation (COOPER) & -0.251 & $0.088^{* * *}$ & -0.041 & 0.036 & 0.029 & 0.029 & 0.262 & $0.101^{* * *}$ \\
\hline International orientation (INTER) & -0.034 & 0.027 & -0.011 & 0.018 & -0.001 & 0.011 & 0.047 & 0.036 \\
\hline \multicolumn{9}{|l|}{ Absorptive capacity } \\
\hline Education level (QUAL) & 0.098 & 0.114 & -0.048 & $0.086^{* *}$ & 0.178 & $0.079^{* *}$ & -0.228 & 0.175 \\
\hline Group membership (APP_GROUP) & 0.048 & 0.094 & -0.019 & 0.038 & 0.031 & 0.037 & -0.060 & 0.119 \\
\hline \multicolumn{9}{|l|}{ Resources } \\
\hline Size (SIZE) & 0.085 & 0.067 & 0.055 & 0.043 & 0.044 & 0.032 & -0.185 & $0.084^{* *}$ \\
\hline Size-squared & -0.004 & 0.008 & -0.004 & 0.004 & -0.004 & 0.004 & 0.012 & 0.010 \\
\hline Firm vintage (AGE) & -0.009 & $0.005^{*}$ & -0.005 & 0.003 & 0.002 & 0.001 & 0.012 & $0.006^{*}$ \\
\hline \multicolumn{9}{|l|}{ The aims of the innovation } \\
\hline $\begin{array}{l}\text { Replace obsolete services } \\
\text { (SERV_OBS) }\end{array}$ & 0.042 & 0.026 & -0.004 & 0.015 & -0.007 & 0.010 & -0.031 & 0.032 \\
\hline $\begin{array}{l}\text { Improve service quality } \\
\text { (QUAL_SERV) }\end{array}$ & -0.035 & 0.039 & 0.132 & 0.062 & -0.025 & 0.021 & -0.072 & 0.076 \\
\hline $\begin{array}{l}\text { Extend the line of services } \\
\text { (GAM_SERV) }\end{array}$ & -0.022 & 0.028 & 0.042 & 0.027 & 0.021 & 0.013 & -0.041 & 0.042 \\
\hline $\begin{array}{l}\text { Sustain the market share } \\
\text { (PART_MAR) }\end{array}$ & -0.052 & 0.040 & -0.138 & $0.061^{* *}$ & 0.021 & 0.018 & 0.169 & $0.081^{* *}$ \\
\hline $\begin{array}{l}\text { Reduce production cost } \\
\text { (RED_COUT) }\end{array}$ & -0.027 & 0.020 & -0.018 & 0.019 & -0.025 & $0.011^{* *}$ & 0.071 & $0.035^{* *}$ \\
\hline Log-likelihood & \multicolumn{8}{|c|}{-6964.8497} \\
\hline Likelihood Ratio statistic (LR) & \multicolumn{8}{|c|}{10119.297} \\
\hline Prob $>$ LR & \multicolumn{8}{|l|}{$[0.000]$} \\
\hline AIC & \multicolumn{8}{|l|}{14013.7} \\
\hline $\mathrm{BIC}$ & \multicolumn{8}{|c|}{14122.69} \\
\hline$R$ squared & \multicolumn{8}{|l|}{0.42} \\
\hline Number of observation & \multicolumn{8}{|l|}{99} \\
\hline
\end{tabular}

Significance level: ${ }^{* *} p<1 \%,{ }^{* *} p<5 \%,{ }^{*} p<10 \%$

research centers, etc.), its ability to innovate in services increases (Table 5). This result is also obtained by Becker and Dietz (2004). These authors show that cooperation with partners in R\&D has a positive and statistically significant effect on innovation. Also, Mohnen et al. (2005) notice that the Canadian manufacturing firms are better-off with innovation while cooperating with other companies. Moreover, we find that the international orientation (INTER) of a firm abroad can promote the ability of innovation. In the same way, Kafouros et al. (2008) show that the internationalization process allows firms to increase their performance through the introduction of new products on the market. As indicated in Tables 4 and 5, the variables Cooper and INTER have no effect on the distinction between the types of service innovation. 
Table 5 Marginal effects of multinomial Probit model for innovation choice (second model)

\begin{tabular}{|c|c|c|c|c|c|c|c|c|}
\hline \multirow[t]{3}{*}{ Variables } & \multirow{2}{*}{\multicolumn{2}{|c|}{ Probit model }} & \multicolumn{6}{|c|}{ Multinomial Probit model } \\
\hline & & & \multicolumn{2}{|c|}{$\begin{array}{l}\text { New-to-market } \\
\text { only }\end{array}$} & \multicolumn{2}{|c|}{$\begin{array}{l}\text { New-to-firm } \\
\text { only }\end{array}$} & \multicolumn{2}{|l|}{ Both } \\
\hline & dy/dx & SE & dy/dx & SE & $d y / d x$ & SE & $d y / d x$ & SE \\
\hline \multicolumn{9}{|l|}{ Internal knowledge sourcing } \\
\hline $\begin{array}{l}\text { Engaging in innovation activities } \\
\text { (ENGAG) }\end{array}$ & -0.193 & 0.120 & -0.062 & 0.041 & -0.029 & 0.023 & 0.091 & $0.048^{*}$ \\
\hline \multicolumn{9}{|l|}{ External knowledge sourcing } \\
\hline Cooperation (COOPER) & 0.191 & $0.087^{* *}$ & -0.039 & 0.044 & 0.025 & 0.029 & 0.014 & 0.057 \\
\hline International orientation (INTER) & 0.040 & $0.020^{* *}$ & -0.010 & 0.019 & 0.000 & 0.011 & 0.010 & 0.023 \\
\hline \multicolumn{9}{|l|}{ Absorptive capacity } \\
\hline Education level (QUAL) & 0.060 & 0.125 & -0.041 & 0.085 & 0.164 & $0.087^{* * *}$ & -0.122 & 0.124 \\
\hline Group membership (APP GROUP) & 0.057 & 0.046 & -0.022 & 0.036 & 0.037 & 0.035 & -0.014 & 0.056 \\
\hline \multicolumn{9}{|l|}{ Ressources } \\
\hline Size (SIZE) & -0.007 & 0.048 & 0.063 & 0.044 & 0.057 & 0.036 & -0.121 & $0.056^{* *}$ \\
\hline Size-squared & -0.003 & 0.006 & -0.005 & 0.004 & -0.005 & 0.004 & 0.010 & $0.006^{*}$ \\
\hline Firm vintage (AGE) & 0.009 & 0.005 & -0.004 & 0.003 & 0.001 & 0.001 & 0.002 & 0.003 \\
\hline \multicolumn{9}{|l|}{ The aims of the innovation } \\
\hline Replace obsolete services (SERV_OBS) & -0.023 & 0.020 & -0.002 & 0.013 & -0.006 & 0.010 & 0.009 & 0.017 \\
\hline Improve service quality (QUAL_SERV) & 0.043 & 0.045 & 0.119 & $0.056^{* *}$ & -0.021 & 0.021 & -0.097 & $0.059^{*}$ \\
\hline $\begin{array}{l}\text { Extend the line of services } \\
\text { (GAM_SERV) }\end{array}$ & 0.020 & 0.022 & 0.038 & 0.024 & 0.021 & 0.014 & -0.059 & $0.029^{* *}$ \\
\hline Sustain the market share (PART_MAR) & 0.037 & 0.037 & -0.125 & $0.056^{* *}$ & 0.015 & 0.019 & 0.110 & $0.060^{*}$ \\
\hline Reduce production cost (RED_COUT) & 0.037 & $0.019^{*}$ & -0.019 & 0.019 & -0.025 & $0.010^{* *}$ & 0.044 & $0.023^{*}$ \\
\hline Log-likelihood & \multicolumn{2}{|c|}{-1526.3879} & \multicolumn{6}{|c|}{-4360.0491} \\
\hline Likelihood Ratio statistic (LR) & \multicolumn{2}{|c|}{20814.832} & \multicolumn{6}{|c|}{6830.8306} \\
\hline Prob $>$ LR & \multicolumn{2}{|l|}{$[0.000]$} & \multicolumn{6}{|l|}{$[0.000]$} \\
\hline $\mathrm{AIC}$ & \multicolumn{2}{|c|}{4627.886} & \multicolumn{6}{|c|}{8776.098} \\
\hline $\mathrm{BIC}$ & \multicolumn{2}{|c|}{4664.217} & \multicolumn{6}{|c|}{8842.443} \\
\hline$R$ squared & \multicolumn{2}{|l|}{0.80} & \multicolumn{6}{|l|}{0.44} \\
\hline Number of observation & \multicolumn{2}{|l|}{99} & \multicolumn{6}{|l|}{79} \\
\hline
\end{tabular}

Significance level: ${ }^{* *} p<1 \%,{ }^{* *} p<5 \%,{ }^{*} p<10 \%$

For both models (M1 and M2), we show that the variable ENGAG positively affects the choice of any innovation type. Despite the difference in the measurement of knowledge activities, similar effects are obtained by Du et al. (2007). These authors consider the internal $R \& D$ (binary variable indicating whether or not the firm has developed $R \& D$ activities) as a measure of knowledge activities rather than a dichotomous variable introducing all innovation activities including the intramural R\&D. This result suggests that if a firm decides to enter the innovation process, it becomes more incentive to innovate.

For both models, our econometric estimations show significant effects concerning the importance service firms give to the innovation objectives. We find that the variable "service quality improvement" is positively related to the choice of new-to-market innovation. In this context, we can note that service quality can be regarded as an objective, among others, that encourages firms to introduce a new service on the market. 
It allows them to gain a competitive advantage and meet the consumers' needs. Furthermore, our results assert that the variable "production costs reduction" positively affects the likelihood of both new-to-market and new-to-firm innovation. This result has been also noted by Sirilli and Evangelista (1998) in the case of both manufacturing and service sectors. We relate this result to the fact that cost-reducing innovation gives the service firms extra opportunities to set lower prices relative to their rivals. This allows each service firm increasing its ability to steal additional customers from its competitors. Finally, we show that the innovation ability is positively correlated with the variable "extend the lines of services". This goes in line with the service firm's quality objective.

\section{Conclusions}

In this paper, we have used a sample of 108 Tunisian service firms in order to explain the extent to which the service firms make their decision to innovate. More precisely, we have tested the robustness of two decision-making models. The first model studies the case where the firm takes a simultaneous innovation decision (a one-stage decision). The second one studies a sequential innovation decision (a two-stage decision).

We have used the Multinomial Probit Model (MNP) in our work. The estimation results of the MNP, using the maximum likelihood method, show that the sequential innovation decision has a positive and statistically significant effect in terms of the innovation decision predictions. Besides, we show that the variable "production cost reduction" positively affects the firm's ability to innovate. Furthermore, our estimation results indicate that the variable "service quality improvement" is positively correlated to the choice of new-to-market innovation. In this line, we conclude that the main objective that encourages firms to introduce a new service on the market is service quality. Moreover, we deduce the fact that the market share is a goal that incites firms to innovate. Another important conclusion is related to the role of both variables "firm collaboration with external partners" and "firm international orientation". In fact, our analysis indicates that these two variables encourage and incite firms to innovate in services. This outcome is also obtained in the literature dealing with innovation.

Further, our analysis conveys some other interesting results relative to the literature that deals with the topic of service innovation. Indeed, these results suggest some policy implications for managers and business leaders. The analysis of the way by which service firms make the decision to innovate is necessary. This is particularly relevant for those interested in an overview of how firms innovate in the business sector. Our results can be useful insights for researchers, service contractors and managers. Besides, one can learn from this paper that the sequential model may help firms to avoid the risk that the radical innovation (or the R\&D program) they will undertake would fail especially as the service sector is characterized by speedy and dynamic innovation process.

As for the limitations of our paper, we argue that the decision of (some) service firms (such as software, telecoms and media) to innovate is crucially related to the innovation making-decision of manufacturing firms (such as hardware, network, 
spectrum). This analysis is outside the scope of our paper. It is a primary avenue for further research.

\section{Endnotes}

${ }^{1}$ The literature on open innovation is abundant. We cite, among others, Jeon et al. (2015), Patra and Krishna (2015), Hossain (2015), etc.

${ }^{2}$ To our best knowledge, the frameworks on service open innovation are Mina et al. (2014), Battisti et al. (2015) Schueffel and Vadana (2015), etc. Our paper does not deal with open innovation. We are specifically interested in analyzing the service firms' innovation making-decision procedures.

${ }^{3}$ For more details, see the report of the Ministry of Scientific Research and Competences Development in Tunisia (2005).

${ }^{4}$ For more details, see Greene (2003) Chapter 21, p728.

${ }^{5} \mathrm{~A}$ French version of the questionnaire could be provided upon request.

${ }^{6}$ National Institute of the Statistics (INS): distribution of companies by activity and by number of employees in 2007.

${ }^{7}$ For more details, see Kotabe et al. (2002).

${ }^{8}$ Where $\widehat{\beta}_{M V}^{*}$ and $\widehat{\beta}_{M V}$ represent respectively the estimator of the constraint model and the estimator of the non-contraint model.

Authors' contribution

The authors contributed equally to this work. Both authors read and approved the final manuscript.

\section{Competing interests}

The authors declare that they have no competing interests.

Received: 22 March 2016 Accepted: 27 August 2016

Published online: 07 September 2016

\section{References}

Akaike, H. (1974). A new look at the statistical model identification. Automatic Control, IEEE Transactions on, 19(6), 716-723.

Baldwin, J., \& Hanel, P. (2003). Innovation and knowledge creation in an open economy: Canadian industry and international implications. Cambridge: Cambridge Univ Press.

Battisti, G., Gallegob, J., Rubalcabac, L., \& Windrumd, P. (2015). Open innovation in services: knowledge sources, intellectual property rights and internationalization. Economics of Innovation and New Technology, 24(3), 223-247.

Becker, W., \& Dietz, J. (2004). R\&D cooperation and innovation activities of firms- evidence for the German manufacturing industry. Research Policy, 33(2), 209-223.

Bourke, J., \& Jordan, D. (2015). A two-stage examination of business innovation decision-making: evidence from Ireland. International Journal of Business Innovation and Research, 9(6), 663-681. doi:10.1504/IJBIR.2015.072489.

Brouwer, E., \& Kleinknecht, A. (1996). Determinants of innovation. A microeconometric analysis of three alternative innovation output indicators. In Determinants of Innovations. The Message from New Indicators (pp. 99-124). London: Macmillan.

Cabagnols, A., \& Le Bas, C. (2002). Differences in the determinants of product and process innovations: the French case. In Innovation and Firm Performance (pp. 112-149). London: Palgrave.

Cainelli, G., Evangelista, R., \& Savona, M. (2006). Innovation and economic performance in services: a firm-level analysis. Cambridge Journal of Economics, 30(3), 435.

Chesbrough, H. (2003). Open innovation: the new imperative for creating and profiting from technology. Boston: MBS.

Cohen, W., \& Levinthal, D. (1990). Absorptive capacity: a new perspective on learning and innovation. Administrative Science Quarterly, 35(1), 128-152.

Crépon, B., Duguet, E., \& Mairessec, J. (1998). Research, innovation and productivity: an econometric analysis at the firm level. Economics of Innovation and New Technology, 7(2), 115-158.

Du, J., Love, J., \& Roper, S. (2007). The innovation decision: An economic analysis. Technovation, 27(12), 766-773.

Duguet, E. (2006). Innovation height, spillovers and TFP growth at the firm level: Evidence from French manufacturing. Economics of Innovation and New Technology, 15(4), 415-442.

Gallouj, F., \& Weinstein, O. (1997). Innovation in services. Research policy, 26(4-5), 537-556.

Greene, W. (2003). Econometric analysis (5th ed.). Upper Saddle River: Prentice Hall.

Hossain, M. (2015). A review of literature on open innovation in small and medium-sized enterprises. Journal of Global Entrepreneurship Research, 5, 6. doi:10.1186/s40497-015-0022-y.

Jeon, J.-H., Kim, S.-K., \& Koh, J.-H. (2015). Historical review on the patterns of open innovation at the national level: the case of the roman period. Journal of Open Innovation: Technology, Market, and Complexity, 1, 20. doi:10.1186/ s40852-015-0026-4. 
Kafouros, M., Buckley, P., Sharp, J., \& Wang, C. (2008). The role of internationalization in explaining innovation performance. Technovation, 28(1-2), 63-74.

Kotabe, M., Srinivasan, S., \& Aulakh, P. (2002). Multinationality and firm performance: the moderating role of R\&D and marketing capabilities. Journal of International Business Studies, 33(1), 79-97.

Lööf, H., \& Heshmati, A. (2006). On the relationship between innovation and performance: a sensitivity analysis. Economics of Innovation and New Technology, 15(4), 317-344.

Mina, A., Bascavusoglu-Moreau, E., \& Hughes, A. (2014). Open service innovation and the firm's search for external knowledge. Research Policy, 43(5), 853-866.

Mairesse, J., \& Mohnen, P. (2003). R\&D and productivity: a reexamination in light of the innovation surveys. In DRUID Summer Conference (pp. 12-14).

Mansury, M., \& Love, J. (2008). Innovation, productivity and growth in US business services: a firm-level analysis. Technovation, 28(1-2), 52-62.

Mohnen, P., Therrien, P., \& CIRANO. (2005). Comparing the innovation performance in Canadian, French and German manufacturing enterprises. Montreal: CIRANO.

MSRCD. (2005). Report of the ministry of scientific research and competences development (msrcd): Les dépenses de r\&d et dinnovation des entreprises en Tunisie.

OCDE, E. (2005). La mesure des activités scientifiques et technologiques. In Manuel d'Oslo, Principes directeurs pour le recueil et l'interprétation des données sur linnovation».

Patra, S. K., \& Krishna, V. V. (2015). Globalization of R\&D and open innovation: linkages of foreign R\&D centers in India. Journal of Open Innovation: Technology, Market, Complexity, 1, 7. doi:10.1186/s40852-015-0008-6.

Paul, M., Planes, B., Huiban, J., \& Sevestre, P. (2000). Externalisation or spillovers? R\&D activity components and the firm performances. In Communication à la journée de travail UMR/ERUDITE, Changement technique, innovation et espace.

Raymond, L., \& St-Pierre, J. (2010). R\&D as a determinant of innovation in manufacturing SMEs: An attempt at empirical clarification. Technovation, 30(1), 48-56.

Roper, S., \& Dundas, H. (1998). Innovation, networks and the diffusion of manufacturing best practice. In NIERC Research Report 14.

Schumpeter, J. (1934). The theory of economic development. Cambridge: Harvard University Press.

Schwarz, G. (1978). Estimating the dimension of a model. In The annals of statistics (pp. 461-464).

Sdiri, H., Ayadi, M., \& Elj, M. (2010). Innovation and performance: an empirical study of Tunisian service firms. Journal of Innovation and Business Best Practices, 2010, 9

Schueffel, P., \& Vadana, I. (2015). Open Innovation in the financial services sector - a global literature review. Journal of Innovation Management, 3(1), 25-48.

Sirilli, G., \& Evangelista, R. (1998). Technological innovation in services and manufacturing: results from Italian surveys. Research Policy, 27(9), 881-899.

Sundbo, J., \& Gallouj, F. (1998). Innovation as a loosely coupled system in services. International Journal of Services Technology and Management, 1(1), 15-36.

\section{Submit your manuscript to a SpringerOpen ${ }^{\circ}$ journal and benefit from:}

- Convenient online submission

- Rigorous peer review

- Immediate publication on acceptance

- Open access: articles freely available online

- High visibility within the field

- Retaining the copyright to your article 